\title{
The cell-envelope proteome of Bifidobacterium longum in an in vitro bile environment
}

\section{Correspondence \\ Abelardo Margolles amargolles@ipla.csic.es}

Received 13 September 2008 Revised 22 November 2008 Accepted 4 December 2008

\author{
Lorena Ruiz, ${ }^{1}$ Yohann Couté, ${ }^{2}$ Borja Sánchez, ${ }^{3}$ Clara G. de los Reyes-Gavilán, ${ }^{1}$ \\ Jean-Charles Sanchez ${ }^{2}$ and Abelardo Margolles ${ }^{1}$
}

\author{
${ }^{1}$ Instituto de Productos Lácteos de Asturias, Consejo Superior de Investigaciones Científicas \\ (CSIC), Ctra Infiesto s/n, 33300, Villaviciosa, Asturias, Spain \\ ${ }^{2}$ Biomedical Proteomics Research Group, Department of Structural Biology and Bioinformatics, \\ University of Geneva, 1 Rue Michel Servet, 1211 Geneva 14, Switzerland \\ 3UMR 5248 CBMN, CNRS-Université Bordeaux 1-ENITAB, Laboratoire de Microbiologie et \\ Biochimie Appliquée, 1 cours du Général de Gaulle, 33175 Gradignan CEDEX, France
}

\begin{abstract}
Host-bacteria interactions are often mediated via surface-associated proteins. The identification of these proteins is an important goal of bacterial proteomics. To address how bile can influence the cell-envelope proteome of Bifidobacterium longum biotype longum NCIMB 8809, we analysed its membrane protein fraction using stable isotope labelling of amino acids in cell culture (SILAC). We were able to identify 141 proteins in the membrane fraction, including a large percentage of the theoretical transporters of this species. Moreover, the envelope-associated soluble fraction was analysed using different subfractionation techniques and differential in-gel fluorescence electrophoresis (DIGE). This approach identified 128 different proteins. Some of them were well-known cell wall proteins, but others were highly conserved cytoplasmic proteins probably displaying a 'moonlighting' function. We were able to identify 11 proteins in the membrane fraction and 6 proteins in the envelope-associated soluble fraction whose concentration varied in the presence of bile. Bile promoted changes in the levels of proteins with important biological functions, such as some ribosomal proteins and enolase. Also, oligopeptidebinding proteins were accumulated on the cell surface, which was reflected in a different tripeptide transport rate in the cells grown with bile. The data reported here will provide the first cell-envelope proteome map for $B$. longum, and may contribute to understanding the bile tolerance of these bacteria.
\end{abstract}

\section{INTRODUCTION}

Bifidobacteria are commensal inhabitants of the gastrointestinal tract of mammals, in which they are involved in the maintenance of an ecological balance by influencing the composition of the gut. They are important components of the gut microbiota, and they may be present at concentrations of $10^{9}-10^{11}$ cells per $\mathrm{g}$ faeces, representing the majority of the microbial gut population in the colon during the early stage of life (Harmsen et al., 2000; Langendijk et al., 1995). Furthermore, bifidobacteria are target species for prebiotics, and some strains are known to beneficially modulate several host-cell functions, the most prevalent of which are the immune responses and intestinal barrier integrity, although the molecular basis of these promoting effects is still largely unknown (Marco et al.,

Abbreviations: DIGE, differential in-gel fluorescence electrophoresis; SILAC, stable isotope labelling of amino acids in cell culture.

Three supplementary tables are available with the online version of this paper.
2006; Salminen et al., 2005). For all these reasons, these micro-organisms are attractive probiotic candidates for inclusion in functional food products, normally being consumed as adjunct cultures in fermented dairy products (Masco et al., 2005).

The functionality of probiotics depends on their ability to survive and temporarily persist in the human host. During digestion, bile is secreted into the intestine in order to solubilize and facilitate the absorption of liposoluble nutrients. Bile salts are detergent-like molecules with a strong antimicrobial activity, which induces membrane damage and causes oxidative stress to the DNA (Begley et al., 2005; Ruiz et al., 2007). Thus, the adaptation of bifidobacteria to bile salts, present in the colon at concentrations usually below $5 \mathrm{mM}$ (Hofmann, 1999), is critical for the colonization of the gut. Additionally, in some bacteria that can be found in the intestine, such as Campylobacter jejuni, bile is the signal that promotes the secretion of specific proteins which are essential for 
adaptation to the gastrointestinal ecosystem (Rivera-Amill et al., 2001).

Some of the more important advances in our understanding of how probiotic bacteria are able to differentially modulate host-cell function were made upon the identification of bacterial cell constituents that modulate downstream responses (Marco et al., 2006). Most of these factors are components localized either in the secreted fraction or in the cell envelope (cell wall or membrane), since this is the part of commensal gut bacteria that is directly exposed to the intestinal epithelium (Candela et al., 2007; Hoarau et al., 2006, 2008; Ivanov et al., 2006; Marco et al., 2006; Mitsuma et al., 2008). However, currently there are to our knowledge no data about this important subproteome in the genus Bifidobacterium.

Our previous studies on the influence of bile on the physiology of different Bifidobacterium species indicated that bile is a host signal that triggers several changes on the cell surface (Gueimonde et al., 2005; Ruiz et al., 2007). Therefore, as a first step towards understanding the interactions of Bifidobacterium with the host, mediated by surface proteins, a functional proteome strategy was developed to unravel the envelope proteome of B. longum, which combines methods based on stable isotope labelling of amino acids in cell culture (SILAC) (Ong et al., 2002), serial extraction of surface proteins, and differential in-gel fluorescence electrophoresis (DIGE) (Marouga et al., 2005). Subsets of cytoplasmic, membrane and cell wall proteins were identified and quantified.

\section{METHODS}

Bacterial strain and growth conditions. B. longum NCIMB 8809 (National Collection of Industrial and Marine Bacteria, Aberdeen, Scotland, UK), which was originally isolated from nursling stools, was used for this study. The inoculum was obtained by culturing the strain on MRS agar plates (BD Diagnostic Systems) supplemented with $0.05 \%(\mathrm{w} / \mathrm{v})$ L-cysteine (Merck) (MRSC), and subsequently an isolated colony was transferred to MRSC broth and grown overnight. The inoculum was washed three times with semidefined medium for B. longum (SDMBL, Couté et al., 2007), resuspended in this medium, and diluted appropriately in 1 litre of SDMBL [containing a sublethal concentration of bile salts, $0.6 \mathrm{~g} \mathrm{l}^{-1}$ (Ox bile extract LS55; Oxoid), when needed] to allow B. longum to grow for 13 generations and the harvesting of the cells in the exponential phase of growth $\left(\mathrm{OD}_{600} 0.4-\right.$ 0.8 ), as previously described (Couté et al., 2007). For SILAC analysis of proteins from the membrane fraction, one of the cultures (control or bile-containing culture, depending on the pair) was grown in the presence of $\left[6-{ }^{13} \mathrm{C}\right]$ leucine. The same growth conditions were applied for the cultures obtained for the extraction of soluble proteins from the cell envelope, but using unlabelled leucine. Bacteria were incubated at $37^{\circ} \mathrm{C}$ in an anaerobic chamber (Bactron Anaerobic/ Environmental Chamber, Sheldon Manufacturing) in an atmosphere of $5 \% \mathrm{CO}_{2} / 5 \% \mathrm{H}_{2} / 90 \% \mathrm{~N}_{2}$, or alternatively in anaerobic jars (Anaerocult A System; Merck).

Preparation of membrane vesicles and SILAC analysis. One litre of B. longum culture was harvested by centrifugation (10000 $\mathrm{g}$ for $15 \mathrm{~min}$ ) and washed twice with $100 \mathrm{mM}$ potassium phosphate buffer, $\mathrm{pH}$ 7.0. Inside-out (ISO) membrane vesicles were obtained essentially as indicated by Sánchez et al. (2006), with minor modifications (Fig. 1). The cell pellet was resuspended in $20 \mathrm{ml} 100 \mathrm{mM}$ potassium phosphate buffer, $\mathrm{pH} 7.0$, supplemented with $10 \mathrm{mM} \mathrm{MgSO}_{4}$, and treated with $10 \mathrm{mg}$ lysozyme $\mathrm{ml}^{-1}$ and 50 units mutanolysin $\mathrm{ml}^{-1}$. The suspension was incubated at $37{ }^{\circ} \mathrm{C}$ for $4 \mathrm{~h}$. Cells were broken by passage three times through a French pressure cell (138 MPa) (SLM \& Aminco) and the suspension was incubated for $20 \mathrm{~min}$ at $30{ }^{\circ} \mathrm{C}$ with $100 \mu \mathrm{l}$ DNase A ml ${ }^{-1}$ (Sigma-Aldrich). Unbroken cells and cell debris were removed by two centrifugation steps at $13000 \mathrm{~g}$ for $20 \mathrm{~min}$ at $4{ }^{\circ} \mathrm{C}$. Membrane vesicles were collected by centrifugation at $125000 \mathrm{~g}$ for $60 \mathrm{~min}$ at $4{ }^{\circ} \mathrm{C}$, and resuspended in $1 \mathrm{ml} 50 \mathrm{mM}$ bicarbonate buffer. Total membrane protein was assayed by the Lowry method in the presence of $0.5 \%(\mathrm{w} / \mathrm{v})$ SDS, using BSA as the standard. To further purify the membrane extracts, a carbonate fractionation procedure was applied (Molloy et al., 2000). Approximately $3 \mathrm{mg}$ membrane protein was dissolved in $1 \mathrm{ml}$ ice-cold $\mathrm{Na}_{2} \mathrm{CO}_{3} 100 \mathrm{mM}$ ( $\mathrm{pH} 11)$ and left on ice for $1 \mathrm{~h}$, being vigorously shaken every $5 \mathrm{~min}$. The carbonate-treated membranes were collected by ultracentrifugation, the supernatant was discarded and the membrane pellet was resuspended and washed in $100 \mu 150 \mathrm{mM}$ bicarbonate buffer. The pellet was collected by ultracentrifugation and resuspended in $60 \mathrm{ml}$ $50 \mathrm{mM}$ bicarbonate buffer. Membranes were stored at $-80{ }^{\circ} \mathrm{C}$ until use.

For SILAC analysis, three independent experiments were carried out. Each experiment was designed for a pair of cultures: a control culture (non-bile-containing SDMBL broth) and a bile-containing culture. In each pair, one of the cultures was grown with normal leucine and the other with $\left[6-{ }^{13} \mathrm{C}\right]$ leucine, as previously described in detail by Couté et al. (2007). Membrane extracts for each pair were mixed at theoretical protein concentration ratios of $1: 1$, and $30 \mu \mathrm{g}$ of the mix was run on SDS-PAGE gels. Twenty-seven different fractions, including the proteins with molecular masses ranging from 220 to $20 \mathrm{kDa}$, were excised from the gel, proteins were in-gel digested with trypsin, and the resulting peptides were extracted and analysed by tandem mass spectrometry (4700 MALDI-TOF/TOF, MDS Sciex). Peptides and proteins were identified using Phenyx software (Genebio) and the NCBI non-redundant database. Proteins were considered as identified if they contain at least one peptide with score and $P$-value above respectively 6.0 and $1 \times 10^{-4}$. The SILAC ratio was determined by averaging the isotope cluster areas of heavy and light peptides identified for each protein using MALDIPepQuant, an inhouse software specifically developed for SILAC data acquired on a MALDI-TOF/TOF instrument (Couté et al., 2007). To evaluate the effect of bile the mean of the SILAC ratios from the three independent batches was considered.

Extraction of soluble cell-envelope-associated proteins and their qualitative analysis. One litre of $B$. longum culture was collected by centrifugation, washed twice in $50 \mathrm{mM}$ potassium phosphate buffer, $\mathrm{pH} \mathrm{7,} \mathrm{and} \mathrm{a} \mathrm{sequential} \mathrm{fractionation} \mathrm{procedure}$ was followed (Fig. 1). First, the pellet was resuspended in $40 \mathrm{ml} 2 \mathrm{M}$ KSCN and incubated for 20 min on ice, being vigorously mixed every 5 min. Cells were pelleted and the supernatant (fraction 1) was kept for further analysis. The pellet was resuspended in $20 \mathrm{ml}$ of the same buffer and broken by a single pass through a Cell Disrupter (Constant Systems). Unbroken cells and cell debris were removed from the solution by centrifugation at $2500 \mathrm{~g}$ for $15 \mathrm{~min}$ and the envelope fraction (composed of membranes and cell walls) was collected by ultracentrifugation at $125000 \mathrm{~g}$ for $20 \mathrm{~min}$. The envelope fractions were resuspended in $2 \mathrm{ml} 50 \mathrm{mM}$ potassium phosphate buffer, $\mathrm{pH} \mathrm{7}$, supplemented with $1 \mathrm{mM} \mathrm{MgSO}_{4}$, and lysozyme and mutanolysin were added to this solution at a final concentration of $0.1 \mathrm{mg} \mathrm{ml} \mathrm{m}^{-1}$ and $0.05 \mathrm{mg} \mathrm{ml}^{-1}$, respectively, to digest the cell wall. This solution was incubated for $4 \mathrm{~h}$ at $37^{\circ} \mathrm{C}$. The proteins released enzymically in the supernatant after this reaction were separated by ultracentrifugation at $125000 \mathrm{~g}$ for $20 \mathrm{~min}$ (fraction 2). The protease inhibitor 


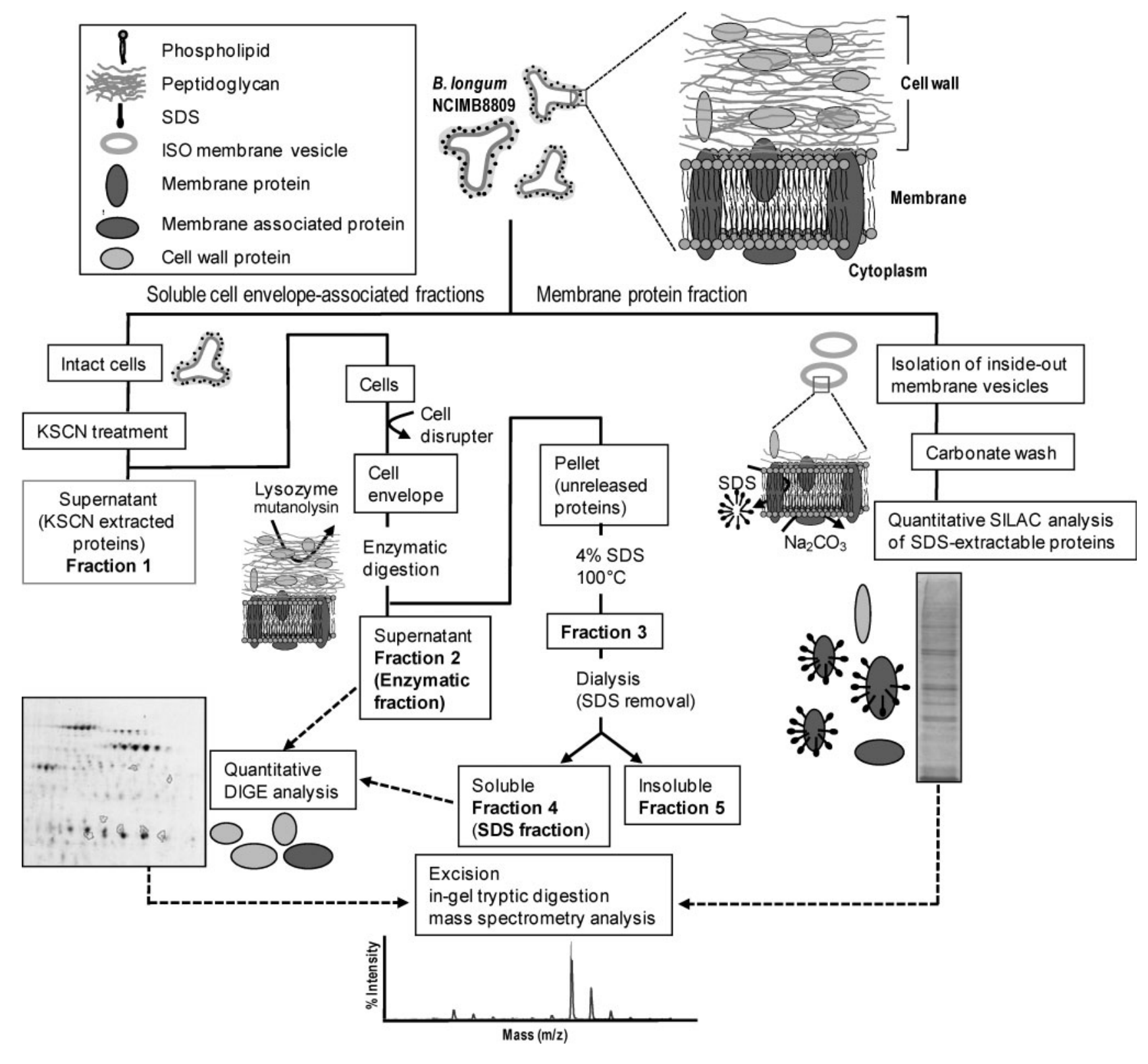

Fig. 1. Overview of the fractionation strategy used to study the cell-envelope proteome of $B$. longum NCIMB 8809 . See text for details.

Pefabloc (0.4 mM; Roche Applied Sciences) was included in all solutions during the procedure. The pellet containing membranes and cell walls with proteins not released during the enzymic treatment was dissolved in $2 \mathrm{ml} 50 \mathrm{mM}$ potassium phosphate buffer, $\mathrm{pH} \mathrm{7}$, supplemented with $4 \%(\mathrm{w} / \mathrm{v})$ SDS. This solution was boiled for $20 \mathrm{~min}$ (fraction 3), and subsequently dialysed against 10000 volumes of ultrapure water. After dialysis, the soluble part (fraction 4) and the insoluble part (fraction 5) were collected. All protein fractions were precipitated in the presence of $10 \%(\mathrm{w} / \mathrm{v})$ TCA for $12 \mathrm{~h}$ at $4{ }^{\circ} \mathrm{C}$, resuspended in $80 \%(\mathrm{v} / \mathrm{v})$ acetone, and subjected to nanoHPLC tandem mass spectroscopy in a Thermo Finnigan LTQ apparatus (Thermo Fisher Scientific) in the Proteomic Unit of the PCM (Parque Científico de Madrid), in order to identify the proteins present in the five fractions.
Quantitative determination of cell-envelope-associated proteins. 2D electrophoresis and DIGE analysis were carried out in the Proteomic Unit of the PCM. For DIGE labelling, eight independent cultures (four of them grown in the presence of bile and the other four grown in the absence of bile) were obtained, and two different protein extracts, designated enzymic fraction (similar to fraction 2, but in this case cells were not previously treated with KSCN) and SDS fraction (fraction 4), were analysed per culture. Bile-treated and untreated fractions were randomly paired for comparison and each pair was co-separated on an individual gel strip $(24 \mathrm{~cm})$. Protein samples were minimally labelled with fluorescent cyanine dyes for $2 \mathrm{D}$ DIGE analysis, according to the manufacturer's instructions (GE Healthcare Bio-Sciences). Briefly, Cy3 and Cy5 dyes (400 pmol each) were used to label $150 \mu \mathrm{g}$ of each protein sample and its counterpart, 
respectively. Two pairs of samples were reverse labelled in order to eliminate the possibility of dye labelling bias. An internal standard was generated by pooling $150 \mu \mathrm{g}$ of each sample and labelled with Cy2 (400 pmol), and was combined with each labelled pair. 2D electrophoresis was carried out according to the conditions described elsewhere (Sánchez et al., 2005, 2007). Setting up experiments of the first dimension (with $\mathrm{pH}$ linear gradient $4-7$ and nonlinear $\mathrm{pH}$ range 3-11) allowed us to select nonlinear $\mathrm{pH}$ range 3-11 for both fractions. The gels containing Cy-dye-labelled proteins were visualized by scanning on a Typhoon 9400 (GE Healthcare), resulting in the generation of 24 spot image maps (12 image files for each fraction). The image files were analysed with DeCyder software v6.5, and the spot selection was carried out taking into account spots with statistically significant differential expression (Student's $t$-test). An effect of bile on the expression of proteins was considered to occur if the mean normalized spot volume varied at least 1.5 -fold ( $t$-test, $P<0.05)$. This quantification of the variation was named the induction factor.

Real-time PCR. Samples $(500 \mu \mathrm{l})$ of cultures, grown in the absence and presence of bile, were resuspended in $1 \mathrm{ml}$ RNAprotect bacteria reagent (Qiagen) and RNA was extracted by using the RNeasy mini kit (Qiagen). Contaminant DNA was removed by on-column digestion using the RNase-free DNase set (Qiagen). Then approximately $3 \mu \mathrm{g}$ RNA was reverse transcribed into cDNA using the cDNA archive kit (Applied Biosystems) and the specific oligonucleotide primers BL1386F (GCCAGCTCACCTTCTCCTACAA)/BL1386R (TCACGACGGCGTCGTAAAG) (amplicon of $63 \mathrm{bp}$ in BL1386), BL1389F (CACTTCGCTGGCCTCCTACA)/BL1389R (AGGCCGACGCCAAGGAA) (amplicon of $60 \mathrm{bp}$ in BL1389), BL1160F (TTTGCAGCATTGCGCATT)/BL1160R (TGACGCCGGCCATCAC) (amplicon of $55 \mathrm{bp}$ in BL1160) and BL1161F (CGTGGCTGCAGGATGTGTAC)/BL1161R (GAAGTCGTGGCTTTCGTTGTG) (amplicon of 74 bp in BL1161) were used. For reverse transcription of 16S rRNA, previously described PCR primers (Gueimonde et al., 2004) were used. The cDNA was stored at $-80{ }^{\circ} \mathrm{C}$ until analysis. Real-time RT-PCR was performed in an ABI Prism 7500 machine (Applied Biosystems) using the SYBR green PCR master mix (Applied Biosystems). Thermal cycling consisted of an initial cycle of $95{ }^{\circ} \mathrm{C}$ $10 \mathrm{~min}$ followed by 35 cycles of $95^{\circ} \mathrm{C} 15 \mathrm{~s}$ and $60{ }^{\circ} \mathrm{C} 1 \mathrm{~min}$. The $16 \mathrm{~S}$ rRNA gene was used as endogenous control. Experiments were carried out in duplicate and analysed in duplicate in two independent PCR runs.

Peptide uptake. For peptide accumulation experiments, two tripeptides (Ala-Ala-Ala, and Gly-Gly-Ala) and three dipeptides (Ala-Ala, Gly-Leu and Leu-Pro) were used. B. longum cells were grown in $160 \mathrm{ml}$ SDMBL broth in the conditions described above. Cells were collected and washed twice with $100 \mathrm{mM}$ potassium phosphate buffer, pH 6.5, supplemented with $10 \mathrm{mM} \mathrm{MgSO}_{4}$. Washed cells were resuspended in the same buffer at a final $\mathrm{OD}_{600}$ of approximately 20. 2-Deoxyglucose was added at a final concentration of $10 \mathrm{mM}$ and the suspensions were incubated for $30 \mathrm{~min}$ at $37{ }^{\circ} \mathrm{C}$ to de-energize the cells and deplete them of amino acids (Detmers et al., 1998). Treated cells were washed twice in $100 \mathrm{mM}$ potassium phosphate buffer, $\mathrm{pH} 5.6$, supplemented with $10 \mathrm{mM}$ $\mathrm{MgSO}_{4}$ and dissolved in the same buffer. Glucose was added at a final concentration of $25 \mathrm{mM}$ and the solutions were incubated for $3 \mathrm{~min}$ at $37{ }^{\circ} \mathrm{C}$. A mixture of the oligopeptides was added so each peptide was present at a final concentration of $1000 \mu \mathrm{M}$. Samples were taken $5 \mathrm{~min}$ after the addition of the oligopeptides. The supernatant was collected by centrifugation and stored at $-20{ }^{\circ} \mathrm{C}$ until use. For the analysis of the profile of oligopeptides, the supernatants were derivatized with dabsyl chloride (Sigma) in the presence of $0.15 \mathrm{mM}$ sodium bicarbonate for $15 \mathrm{~min}$ at $70{ }^{\circ} \mathrm{C}$, as previously described (Sánchez et al., 2007). Ten-microlitre samples of the derivatized samples were loaded in a Novapack C18 column (Waters) at a constant temperature of $50{ }^{\circ} \mathrm{C}$, and the peptide derivatives were detected with a UV detector at a wavelength of $436 \mathrm{~nm}$. Experiments were carried out in duplicate and analysed in duplicate in two independent chromatographic analyses.

Bioinformatic analysis. In silico analyses were performed using the database for B. longum NCC 2705 (http://www.ncbi.nlm.nih.gov/ genomes/lproks.cgi). Signal peptides and transmembrane helix predictions were obtained from the CBS Genome Atlas Database (http:// www.cbs.dtu.dk/services/GenomeAtlas). GW modules (Superfamily 22279), lipoprotein anchor domains, LPXTG sorting signals (Pfam: PF00746), LRR regions (Pfam PF00560), LysM domains (Pfam PF01476) and NLPC/P60 domains (Pfam PF00877) were obtained from the pre-computed B. longum NCC 2705 proteome at the AUGUR database (http://141.50.94.20/augur/search/searchMain.php).

\section{RESULTS}

\section{Bioinformatic analysis of the theoretical cell envelope proteome and the secreted proteins of B. longum NCC 2705}

The number of surface-associated proteins in B. longum was predicted through a bioinformatic analysis using dedicated software (Table 1), taking into account the genome annotation of B. longum NCC 2705 (Schell et al., 2002). The results of the different location predictions were combined by grouping the proteins into classes according to signal peptides for export features (145 proteins), at least one hypothetical transmembrane segment (361 proteins), proteins anchored covalently to the peptidoglycan (LPXTG sorting signal; 13 proteins) or to the membrane (lipoprotein motifs; 25 proteins), and proteins which are noncovalently bound to the surface ( 8 proteins). The same software was used to predict the location of the proteins identified in the membrane fractions and in soluble fractions of the cell envelope; this information is provided in Supplementary Tables S1 and S2, available with the online version of this paper.

\section{Identification of cell-envelope-associated proteins of B. longum NCIMB $\mathbf{8 8 0 9}$}

A carbonate washing procedure was applied to the $B$. longum membrane protein fraction in order to get rid of proteins loosely associated with the membrane through electrostatic interactions. In fact, this wash allowed us to eliminate a significant amount of ribosomal proteins (data not shown). Carbonate-washed membrane protein extracts were run on SDS-PAGE gels and the SILAC analysis of the separated fractions allowed the identification of 141 proteins in the membrane protein fraction. These included 23 ribosomal proteins. Also, 78 membrane transporters (or transporter subunits) were identified, representing a large percentage of the theoretical transporters of this bacterium and, probably, the most represented in terms of abundance. Remarkably, 40 proteins without a signal sequence, theoretically targeted to the cytoplasm, were also identified (Supplementary Table S1). 
Table 1. Theoretical secreted proteins of $B$. longum NCC 2705

\begin{tabular}{|lc|}
\hline Export features & Count \\
\hline Predicted localization & \\
Tat signal peptide & 1 \\
Sec signal peptide & 75 \\
Lipoprotein signal peptide & 32 \\
$\quad$ Non-classical secretion & 37 \\
Surface-associated proteins predicted anchoring & \\
$\quad$ Membrane proteins $\dagger$ & 361 \\
Covalently anchored & \\
LPXTG sorting signals $\ddagger$ & 13 \\
Lipoprotein motifs $\$$ & 25 \\
Non-covalently anchored & \\
GW modulesll & 2 \\
LRR region & 3 \\
LysM domains & 1 \\
NLPC/P60 domains 9 & 2 \\
\hline
\end{tabular}

*Signal peptide predictions for B. longum NCC 2705 were obtained from the CBS Genome Atlas Database.

$\dagger$ The presence of at least one transmembrane helix was predicted with TMHMM (Krogh et al., 2001).

\$LPXTG sorting signals (PF00746) were predicted with HMM from Pfam (Bateman et al., 2004).

§Lipoprotein motifs were detected according to the pattern match '[MV].\{0,13\}[RK] [DERKQ] 66,20$\}[$ LIVMFESTAG][LVIAM][IVMSTAFG] [AG]C' (Sutcliffe \& Harrington, 2002).

IIGW modules were predicted with HMM model 22279 from SUPERFAMILY (Madera et al., 2004).

SLRR regions (PF00560), LysM domains (PF01476) and NlpC/P60 domains (PF00877) were predicted with HMM from Pfam (Bateman et al., 2004).

In the analysis of the five different fractions of envelopeassociated soluble proteins (Fig. 1), 128 proteins were identified, of which 38 were ribosomal proteins, 18 were theoretically localized in the surface of Gram-positive bacteria, 25 showed no signal sequence, but had been found previously on the surface of other Gram-positives, and the rest (47 proteins) were hypothetical cytosolic proteins (Supplementary Table S2). Also, 51 proteins were coincident between the membrane and the soluble protein fractions, which yields a total number of identified proteins of 218 .

\section{Quantitative changes associated with the presence of bile salts in the medium}

Preliminary experiments were carried out in order to ascertain the absence of cell lysis, at the time of collecting the cells, in our protein extracts. The $2 \mathrm{D}$ profiles of cellenvelope-associated proteins appeared very different from those of cytoplasmic extracts of B. longum NCIMB 8809 (data not shown), suggesting the absence both of cell lysis and of a major contamination of the cytoplasmic proteins.
A SILAC analysis of the membrane protein fraction was able to identify 11 proteins whose concentration changed in the presence of bile (Supplementary Tables S1 and S2). Only identified proteins that were found to be up- or downregulated in two out of the three SILAC fractions analysed were taken into account for the statistical analysis. The tendency was a marked upregulation of the proteins in the presence of bile; only the aldehyde-alcohol dehydrogenase 2 was found to be downregulated.

On the other hand, we detected $92 \%$ of the soluble cellenvelope-associated proteins in fractions 1,2 and 4. Therefore, they were considered for quantitative determinations. The DIGE analyses of the enzymic fraction (fraction 2 without previous KSCN treatment, containing most of the proteins of fraction 1; Supplementary Table S2) and the SDS fraction (fraction 4) were carried out under nonlinear $\mathrm{pH}$ gradient 3-11, since this gave better spot resolution than the linear $\mathrm{pH}$ range $4-7$, and the protein coverage was higher (Fig. 2). In the enzymic fraction the tendency was contrary to that observed in the membrane protein fraction: most of the proteins were found to be in a lower concentration in the presence of bile (16 out of 18 proteins). For the SDS fraction (fraction 4), 16 proteins were differentially quantified, six of them being downregulated and 10 upregulated (Supplementary Table S3). In the subsequent mass spectrometry analysis six proteins could be identified in both fractions (Table 2). In addition, the proteins represented in a higher amount in the enzymic fraction, in theory the fraction more exposed to the external environment, could be identified as phosphoketolase, glutamine synthetase, elongation factor $\mathrm{Tu}$, enolase and glyceraldehyde-3-phosphate dehydrogenase (Fig. 2).

It is worth highlighting that two oligopeptide transport subunits from two different transport systems (OppA and $\mathrm{DppD}$ ) were detected in a higher amount in the membrane protein fraction, in the soluble fraction, or in both, when the cells were grown in the presence of bile, suggesting the influence of bile on peptide uptake by this bacterium. However, RT-PCR analysis of genes coding for different subunits of these two peptide transport systems (genes BL1386, BL1389, BL1160 and BL1161) did not show an upregulation of the corresponding genes.

\section{Oligopeptide accumulation experiments}

B. longum cells, grown in the absence or presence of bile, were incubated in the presence of a mix of five different oligopeptides. After de-energization of the cells, and subsequent supply of metabolic energy with glucose, the cells grown in the presence of bile were able to remove a higher amount of Ala-Ala-Ala from the medium, when compared with control cells grown in the absence of bile. The concentration of remaining tripeptide in the supernatant of control cells was $770 \pm 133 \mu \mathrm{M}$ after 5 min of incubation, and $532 \pm 50 \mu \mathrm{M}$ for bile-treated cells (initial peptide concentration was $1000 \mu \mathrm{M}, P<0.05)$. However, no statistically significant differences were found for the 


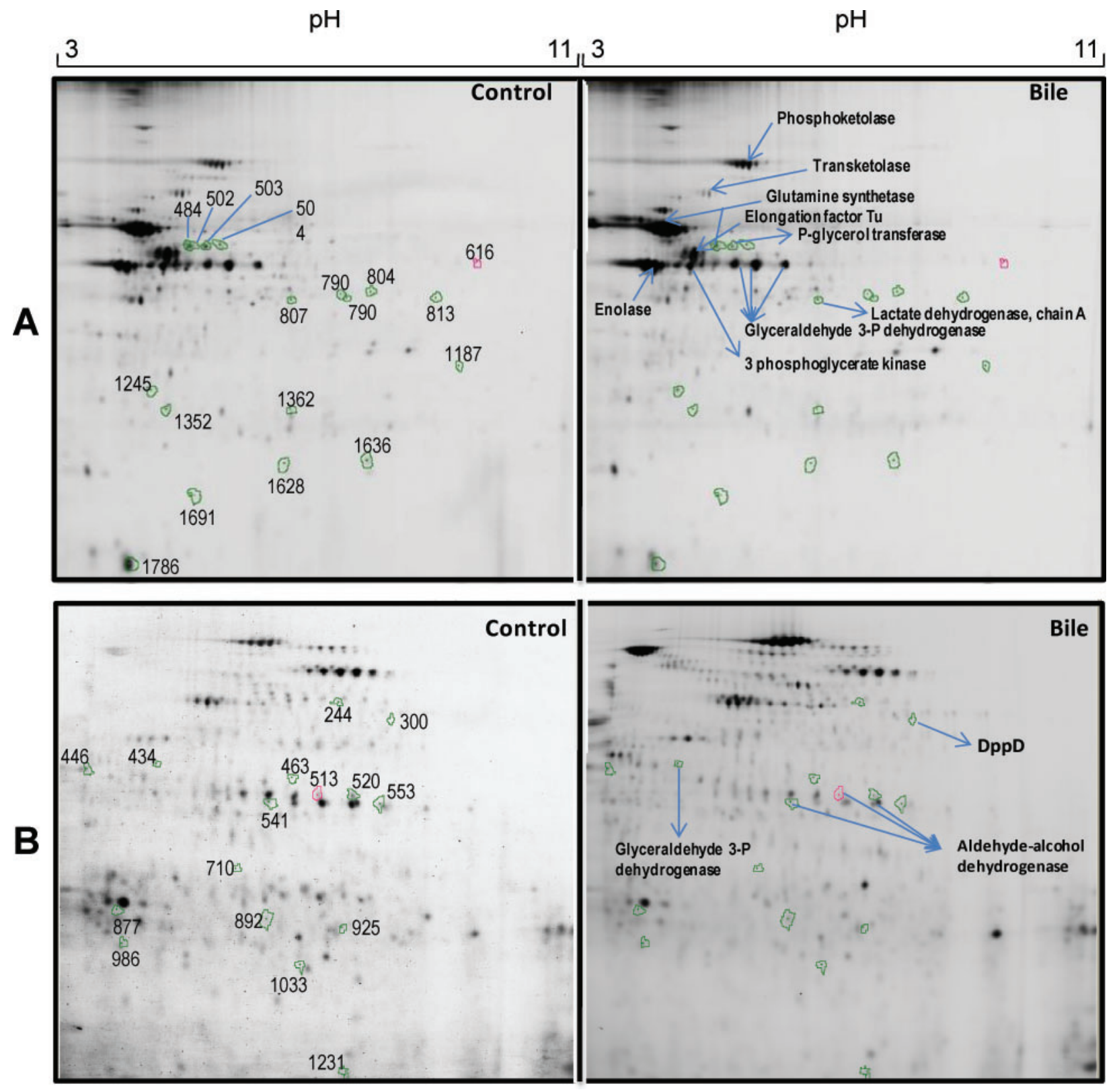

Fig. 2. Representative gels of the DIGE analysis of the soluble cell-envelope-associated protein fractions from $B$. longum NCIMB 8809 extracted by enzymic treatment ( $\mathrm{A}$; enzymic fraction or fraction 2 without previous KSCN treatment) or extracted by SDS treatment and subsequent dialysis (B; SDS fraction or fraction 4). Proteins whose relative abundance in the presence of bile differed from the control by at least \pm 1.5 -fold $(t$-test, $P<0.05)$ are highlighted; their quantitative analysis is shown in Supplementary Table S3. The arrows indicate the identified proteins.

other four peptides (Gly-Gly-Ala, Ala-Ala, Gly-Leu and Leu-Pro), suggesting that the increase of peptide uptake promoted by bile is somehow specific.

\section{DISCUSSION}

In Gram-positive bacteria, proteins can be sorted to four different destinations: the cytoplasm, the membrane, the cell wall and the extracellular environment (Buist et al.,
2006). The study of the cytoplasmic proteome of B. longum under different gastrointestinal conditions ( $\mathrm{pH}$ and bile) in vitro (Sánchez et al., 2005, 2007) and in vivo (Yuan et al., 2008) was accomplished in previous studies. Also, the most abundant proteins secreted by this species were identified (Sánchez et al., 2008). The object of the current work was to map the envelope proteome of B. longum NCIMB 8809, and to determine the influence of bile on its protein composition and on the phenotype derived therefrom. 
Table 2. Identification of envelope-associated proteins of $B$. longum NCIMB 8809 affected by bile exposure

Ez, enzymic fraction (fraction 2 without previous KSCN treatment); SDS, SDS fraction (fraction 4).

\begin{tabular}{|c|c|c|c|c|}
\hline Putative function ${ }^{\star}$ & $\begin{array}{c}\text { Accession } \\
\text { no. } \dagger\end{array}$ & Gene $\ddagger$ & $\begin{array}{c}\text { Mass } \\
(\mathrm{kDa}) \S\end{array}$ & Normalized ratio $\|$ \\
\hline \multicolumn{5}{|l|}{ Membrane protein fraction } \\
\hline Oligopeptide-binding protein of $\mathrm{ABC}$ transporter & BL1161 & oppA & 58.4 & 2.1 \\
\hline ATP-binding protein of peptide $\mathrm{ABC}$ transporter & BL1390 & $d p p D$ & 73.2 & 1.78 \\
\hline Cell division proteins FtsI/penicillin-binding protein 2 & BL0587 & $p b p A$ & 51.2 & 2.22 \\
\hline Rp S3 & BL1584 & $r p s C$ & 30.2 & 2.04 \\
\hline Rp L4 & BL1579 & $r p l D$ & 23.5 & 2.02 \\
\hline Rp S5 & BL1597 & $r p s E$ & 24.6 & 2.14 \\
\hline Rp L6P/L9E & BL1595 & $r p l F$ & 18.9 & 2.02 \\
\hline Rp L5 & BL1592 & rplE & 21.4 & 2.33 \\
\hline Protoporphyrinogen oxidase & BL0399 & - & 60.9 & 1.54 \\
\hline Aldehyde-alcohol dehydrogenase & BL1575 & adh2 & 98.9 & 0.48 \\
\hline Enolase & BL1022 & eno & 46.5 & 3.16 \\
\hline \multicolumn{5}{|l|}{ Soluble protein fraction } \\
\hline Glutamine synthetase (Ez) & BL1076 & gluA1 & 53.3 & 0.35 \\
\hline Phosphoglycerol transferase (Ez) & BL1125 & - & 75.8 & 0.29 \\
\hline Lactate dehydrogenase, chain A (Ez) & BL1308 & ldh2 & 34.4 & 0.57 \\
\hline ATP-binding protein of peptide $\mathrm{ABC}$ transporter (SDS) & BL1390 & $d p p D$ & 73.2 & 1.66 \\
\hline Aldehyde-alcohol dehydrogenase (SDS) & BL1575 & adh2 & 98.9 & 0.58 \\
\hline Glyceraldehyde-3-phosphate dehydrogenase (SDS) & BL1363 & gap & 37.8 & 1.85 \\
\hline
\end{tabular}

${ }^{\star}$ Putative functions were assigned from the KEGG pathways for B. longum NCC 2705.

$\dagger$ Accession number in the NCBI database for B. longum NCC 2705.

\$Gene designation in the National Center for Biotechnology Information (NCBI) database for B. longum NCC 2705.

§As given by the NCBI database for B. longum NCC 2705.

\|SILAC ratio (membrane protein fraction) or induction factor (soluble protein fraction).

For gut bacteria, surface proteins are the prime contact point of the bacterial cell with the host. They possess key functions in the adaptation to the gastrointestinal environment, as well as in the colonization of host tissues, and in the induction of host downstream responses (Kelly et al., 2005a; Marco et al., 2006). In bifidobacteria, claims have been made regarding, for instance, cell-surface proteinaceous components involved in intestinal adhesion (Mukai et al., 2004), proteinaceous factor(s) in culture supernatant fluids of bifidobacteria which prevent(s) the binding of enterotoxigenic Escherichia coli (Fujiwara et al., 1997), or supernatants of Bifidobacterium breve that can modulate transduction signalling pathways and induce maturation in human dendritic cells (Hoarau et al., 2006, 2008). Also, single molecules responsible for a particular effect have been identified. Ivanov et al. (2006) suggested that the $B$. longum serpin, a membrane-anchored protein, inhibits human elastase in vitro, and that expression of this surface protein by $B$. longum leads to reduced intestinal inflammation in a murine colitis model. Also, Bifidobacterium animalis subsp. lactis displays on its cell wall five plasminogen-binding proteins, whose function might be to facilitate the colonization of the human gut through degradation of extracellular matrices (Candela et al., 2007). Recently, a pentapeptide secreted into the culture super- natant of the probiotic bacterium B. animalis subsp. lactis $\mathrm{Bb} 12$ was found to induce the gene expression of interleukin-6 in a human myeloid leukaemic cell line (Mitsuma et al., 2008). In relation to this, with the aim of determining the protein profile of the B. longum envelope, and as a first approach to undertaking deeper functional studies, we analysed different subcellular fractions. The application of gel-based and gel-free technologies, combined with high-throughput techniques, allowed us to identify 218 proteins; about $70 \%$ of them were predicted to be, or were previously described as being, in the cell envelope of Gram-positive bacteria (Antikainen et al., 2007; Candela et al., 2007; Eymann et al., 2004; Granato et al., 2004; Jang \& Hanash 2003; Kelly et al., 2005b; Nandakumar et al., 2005; Rivera-Amill et al., 2001; Rodríguez-Ortega et al., 2006; Schaumburg et al., 2004; Severin et al., 2007; Silveira et al., 2004; Tjalsma et al., 2008; Wolff et al., 2007). Furthermore, 48 of them are predicted to be integral membrane proteins (contain hypothetical transmembrane segments) and 30 of them have different extracytoplasmic sorting signals. In total, this proteomic profile probably represents the proteins most abundantly displayed on the cell envelope of B. longum NCIMB 8809, a human isolate with the capacity to produce an antimicrobial substance (O’Riordan \& Fitzgerald, 1998). 
2D electrophoresis-based workflows, the most popular techniques for the study of bacterial stress responses, do not provide information on hydrophobic proteins, mainly membrane proteins, due to technical difficulties in retaining their solubility during the isoelectrofocusing and limitations in reliable quantification (Bunai \& Yamane, 2005; Speers \& Wu, 2007). Some of these disadvantages have been overcome with new techniques based on improved solubilizing agents or isotopic labelling (Couté et al., 2007; Speers \& Wu, 2007), expanding the possibilities for analysing bacterial membrane subproteomes. In fact, SILAC has recently been successfully applied to the monitoring of changes in the membrane proteome during stationary-phase adaptation of Bacillus subtilis (Dreisbach et al., 2008). We have used this procedure to analyse quantitatively the membrane subproteome of $B$. longum under bile stress conditions. We also adapted different methods of surface protein extraction of Gram-positive bacteria to detect and quantify the changes promoted by bile in the water-soluble protein fraction of the cell envelope (Jang \& Hanash, 2003; Schaumburg et al., 2004), using DIGE analysis. In total, taking into account the membrane protein fraction and the envelope-associated soluble protein fraction, one of the most remarkable findings of this work was the large amount of ribosomal proteins detected: 41 out of the 52 ribosomal proteins annotated in the B. longum NCC 2705 genome were identified. Ribosomal proteins are very often found associated with the cell surface in bacteria, and although they are thought to have a certain affinity for the inner leaflet of the membrane, they have also been detected on the bacterial surface exposed to the external medium (Severin et al., 2007; Tjalsma et al., 2008). In some cases it has even been demonstrated that ribosomal proteins are immunomodulatory for humans (Spence \& Clark, 2000).

One of the key findings of this work is the identification of proteins that may be important for gut survival and adaptation. In fact, the most abundant proteins released after cell wall digestion with lysozyme and mutanolysin, in theory the fraction more exposed to the external environment, could be identified as phosphoketolase, glutamine synthetase, elongation factor $\mathrm{Tu}$, enolase and glyceraldehyde-3-phosphate dehydrogenase. Phosphoketolase is a key enzyme of carbohydrate catabolism in bifidobacteria; previously it has been found to be associated with the bifidobacterial membrane (Sánchez et al., 2004). Glyceraldehyde-3-phosphate dehydrogenase is associated with the cell wall in Lactobacillus crispatus in a $\mathrm{pH}$ dependent manner (Antikainen et al., 2007). Most interestingly, Candela et al. (2007) demonstrated that the glutamine synthetase of $B$. animalis is displayed on the cell wall, and it is able to capture human plasminogen, suggesting a role in the colonization of the human gut. A similar physiological role has been suggested for surfacedisplayed enolase in $B$. animalis and other bacteria (Candela et al., 2007; Knaust et al., 2007). Also, cellsurface-associated elongation factor $\mathrm{Tu}$ mediates the attachment of Lactobacillus johnsonii to human intestinal cells and mucins (Granato et al., 2004). All these five proteins are conserved cytoplasmic proteins lacking any extracytoplasmic sorting sequence, and the mechanisms of secretion and cell anchoring remain to be determined, although increasing evidence points to a biological activity when the proteins are surface exposed which is different from their known cytoplasmic activity (moonlight function) (Jeffery, 2003). All these enzymes also represent good targets for immunology-based detection methods of this genus.

Regarding the quantitative analysis, the ratios of up- and downregulation were considerably lower in this study than in previous stress studies ( $\mathrm{pH}$ and bile) of cytoplasmic proteins of the same strain (Sánchez et al., 2005, 2007). Furthermore, previous work concluded that bile induces deep changes in the lipid composition of bifidobacterial membranes (Ruiz et al., 2007). Thus, it is very likely that the bile predominantly affects the phospholipid composition of the membranes, and the membrane protein composition is affected to a lesser extent.

Five ribosomal proteins were found to be overproduced in the presence of bile. Ribosomal proteins are necessary for ribosome assembly and stability, and in other bacteria they have been involved in sensing environmental changes (Chen et al., 2003; VanBogelen \& Neidhardt, 1990). Some of them are able to modulate the synthesis of metabolic enzymes and the cell fitness in response to stress (Wilson \& Nierhaus, 2005). Remarkably, membrane-associated enolase increased in concentration by a factor of 3.16, which could suggest that bile triggers the production of bacterial factors for intestinal colonization, as has been suggested for bifidobacteria and other intestinal bacteria (Candela et al., 2007; Gueimonde et al., 2005; Rivera-Amill et al., 2001).

In our experiments bile also promoted the accumulation of different components of hypothetical dipeptide (Dpp) and oligopeptide (Opp) transport systems in the membrane and the soluble fraction. However, from RT-PCR experiments we could infer that this phenomenon is not due to a gene induction; thus a post-translational regulation of peptide transport was considered. It is possible that the changes promoted by bile in the physical characteristics of the bifidobacterial surface somehow trap those proteins (Gueimonde et al., 2005; Ruiz et al., 2007). We corroborated the proteomic results with physiological data by investigating differences in dipeptide and tripeptide transport rates. The tripeptide Ala-Ala-Ala was removed from the medium at a higher rate from cells grown in the presence of bile than from control cells. Differences in peptide uptake have been shown in bacteria in response to different environmental factors (Jamieson \& Higgins, 1984), and the involvement of peptide transporters in stress responses has also been suggested (Wouters et al., 2005). The increased peptide uptake could be oriented to counteract the effect of bile (protein misfolding and proteolysis). 
In summary, for many bacteria research is now in the postgenomic era, and Bifidobacterium is no exception. In recent years several cytoplasmic proteomes of B. longum have been studied, although to our knowledge the envelope proteome of this bacterium has never been explored before. A computer-assisted analysis allowed us to infer that $B$. longum, like other Gram-positive bacteria, dedicates large energy resources to produce proteins theoretically localized on the cell surface. We identified 156 proteins predicted to be on the cell envelope of $B$. longum, representing close to $10 \%$ of the total proteome of this bacterium. The interactions of these cell-envelope-associated proteins with human cells might be partially responsible for the probiotic effects of bifidobacteria, so research is currently ongoing to determine their physiological role.

\section{ACKNOWLEDGEMENTS}

This work was financed by European Union FEDER funds and the Spanish Plan Nacional de I+D (project AGL2007-61805 and fellowship PR2006-0421) and by the Swiss National Science Foundation (grant 3100-A0-104214). L. R. was supported by an I3P predoctoral contract granted by CSIC and FEDER funds, and B.S. was the recipient of a Clarín postdoctoral contract from the Gobierno del Principado de Asturias. Jacques M. Deshusses is specially thanked for his excellent assistance in the development of extraction protocols for membrane proteins. Oscar P. Kuipers and Girbe Buist, from the Department of Molecular Genetics of the University of Groningen, are acknowledged for sharing unpublished information.

\section{REFERENCES}

Antikainen, J., Kuparinen, V., Lähteenmäki, K. \& Korhonen, T. K. (2007). pH-dependent association of enolase and glyceraldehyde-3phosphate dehydrogenase of Lactobacillus crispatus with the cell wall and lipoteichoic acids. J Bacteriol 189, 4539-4543.

Bateman, A., Coin, L., Durbin, R., Finn, R. D., Hollich, V., GriffithsJones, S., Khanna, A., Marshall, M., Moxon, S. \& other authors (2004). The Pfam protein families database. Nucleic Acids Res 32, D138-D141.

Begley, M., Gahan, C. G. \& Hill, C. (2005). The interaction between bacteria and bile. FEMS Microbiol Rev 29, 625-651.

Buist, G., Ridder, A. N., Kok, J. \& Kuipers, O. P. (2006). Different subcellular locations of secretome components of Gram-positive bacteria. Microbiology 152, 2867-2874.

Bunai, K. \& Yamane, K. (2005). Effectiveness and limitation of twodimensional gel electrophoresis in bacterial membrane protein proteomics and perspectives. J Chromatogr B Analyt Technol Biomed Life Sci 815, 227-236.

Candela, M., Bergmann, S., Vici, M., Vitali, B., Turroni, S., Eikmanns, B. J., Hammerschmidt, S. \& Brigidi, P. (2007). Binding of human plasminogen to Bifidobacterium. J Bacteriol 189, 5929-5936.

Chen, H., Teplitski, M., Robinson, J. B., Rolfe, B. G. \& Bauer, W. D. (2003). Proteomic analysis of wild-type Sinorhizobium meliloti responses to $\mathrm{N}$-acyl homoserine lactone quorum-sensing signals and the transition to stationary phase. J Bacteriol 185, 5029-5036.

Couté, Y., Hernandez, C., Appel, R. D., Sanchez, J. C. \& Margolles, A. (2007). Labeling of Bifidobacterium longum cells with ${ }^{13} \mathrm{C}$-substituted leucine for quantitative proteomic analyses. Appl Environ Microbiol $73,5653-5656$.
Detmers, F. J., Kunji, E. R., Lanfermeijer, F. C., Poolman, B. \& Konings, W. N. (1998). Kinetics and specificity of peptide uptake by the oligopeptide transport system of Lactococcus lactis. Biochemistry 37, 16671-16679.

Dreisbach, A., Otto, A., Becher, D., Hammer, E., Teumer, A., Gouw, J. W., Hecker, M. \& Völker, U. (2008). Monitoring of changes in the membrane proteome during stationary phase adaptation of Bacillus subtilis using in vivo labeling techniques. Proteomics 8, 2062-2076.

Eymann, C., Dreisbach, A., Albrecht, D., Bernhardt, J., Becher, D., Gentner, S., Tam le, T., Büttner, K., Buurman, G. \& other authors (2004). A comprehensive proteome map of growing Bacillus subtilis cells. Proteomics 4, 2849-2876.

Fujiwara, S., Hashiba, H., Hirota, T. \& Forstner, J. F. (1997). Proteinaceous factor(s) in culture supernatant fluids of bifidobacteria which prevents the binding of enterotoxigenic Escherichia coli to gangliotetraosylceramide. Appl Environ Microbiol 63, 506-512.

Granato, D., Bergonzelli, G. E., Pridmore, R. D., Marvin, L., Rouvet, M. \& Corthésy-Theulaz, I. E. (2004). Cell surface-associated elongation factor Tu mediates the attachment of Lactobacillus johnsonii NCC533 (La1) to human intestinal cells and mucins. Infect Immun 72, 2160 2169.

Gueimonde, M., Tölkkö, S., Korpimäki, T. \& Salminen, S. (2004). New real-time quantitative PCR procedure for quantification of bifidobacteria in human fecal samples. Appl Environ Microbiol 70, 4165-4169.

Gueimonde, M., Noriega, L., Margolles, A., de los Reyes-Gavilán, C. G. \& Salminen, S. (2005). Ability of Bifidobacterium strains with acquired resistance to bile to adhere to human intestinal mucus. Int $J$ Food Microbiol 101, 341-346.

Harmsen, H. J., Wildeboer-Veloo, A. C., Raangs, G. C., Wagendorp, A. A., Klijn, N., Bindels, J. G. \& Welling, G. W. (2000). Analysis of intestinal flora development in breast-fed and formula-fed infants by using molecular identification and detection methods. J Pediatr Gastroenterol Nutr 30, 61-67.

Hoarau, C., Lagaraine, C., Martin, L., Velge-Roussel, F. \& Lebranchu, Y. (2006). Supernatant of Bifidobacterium breve induces dendritic cell maturation, activation, and survival through a Toll-like receptor 2 pathway. J Allergy Clin Immunol 117, 696-702.

Hoarau, C., Martin, L., Faugaret, D., Baron, C., Dauba, A., AubertJacquin, C., Velge-Roussel, F. \& Lebranchu, Y. (2008). Supernatant from Bifidobacterium differentially modulates transduction signaling pathways for biological functions of human dendritic cells. PLoS One 3, e2753.

Hofmann, A. F. (1999). The continuing importance of bile acids in liver and intestinal disease. Arch Intern Med 159, 2647-2658.

Ivanov, D., Emonet, C., Foata, F., Affolter, M., Delley, M., Fisseha, M., Blum-Sperisen, S., Kochhar, S. \& Arigoni, F. (2006). A serpin from the gut bacterium Bifidobacterium longum inhibits eukaryotic elastase-like serine proteases. J Biol Chem 281, 17246-17252.

Jamieson, D. J. \& Higgins, C. F. (1984). Anaerobic and leucinedependent expression of a peptide transport gene in Salmonella typhimurium. J Bacteriol 160, 131-136.

Jang, J. H. \& Hanash, S. (2003). Profiling of the cell surface proteome. Proteomics 3, 1947-1954.

Jeffery, C. J. (2003). Moonlighting proteins: old proteins learning new tricks. Trends Genet 19, 415-417.

Kelly, D., Conway, S. \& Aminov, R. (2005a). Commensal gut bacteria: mechanisms of immune modulation. Trends Immunol 26, 326-333.

Kelly, P., Maguire, P. B., Bennett, M., Fitzgerald, D. J., Edwards, R. J., Thiede, B., Treumann, A., Collins, J. K., O'Sullivan, G. C. \& other authors (2005b). Correlation of probiotic Lactobacillus salivarius growth phase with its cell wall-associated proteome. FEMS Microbiol Lett 252, 153-159. 
Knaust, A., Weber, M. V., Hammerschmidt, S., Bergmann, S., Frosch, M. \& Kurzai, O. (2007). Cytosolic proteins contribute to surface plasminogen recruitment of Neisseria meningitidis. J Bacteriol 189, 3246-3255.

Krogh, A., Larsson, B., von Heijne, G. \& Sonnhammer, E. L. (2001). Predicting transmembrane protein topology with a hidden Markov model: application to complete genomes. J Mol Biol 305, 567-580.

Langendijk, P. S., Schut, F., Jansen, G. J., Raangs, G. C., Kamphuis, G. R., Wilkinson, M. H. \& Welling, G. W. (1995). Quantitative fluorescence in situ hybridization of Bifidobacterium spp. with genusspecific 16S rRNA-targeted probes and its application in fecal samples. Appl Environ Microbiol 61, 3069-3075.

Madera, M., Vogel, C., Kummerfeld, S. K., Chothia, C. \& Gough, J. (2004). The SUPERFAMILY database in 2004: additions and improvements. Nucleic Acids Res 32, D235-D239.

Marco, M. L., Pavan, S. \& Kleerebezem, M. (2006). Towards understanding molecular modes of probiotic action. Curr Opin Biotechnol 17, 204-210.

Marouga, R., David, S. \& Hawkins, E. (2005). The development of the DIGE system: 2D fluorescence difference gel analysis technology. Anal Bioanal Chem 382, 669-678.

Masco, L., Huys, G., De Brandt, E., Temmerman, R. \& Swings, J. (2005). Culture-dependent and culture-independent qualitative analysis of probiotic products claimed to contain bifidobacteria. Int J Food Microbiol 102, 221-230.

Mitsuma, T., Odajima, H., Momiyama, Z., Watanabe, K., Masuguchi, M., Sekine, T., Shidara, S. \& Hirano, S. (2008). Enhancement of gene expression by a peptide $\mathrm{p}(\mathrm{CHWPR})$ produced by Bifidobacterium lactis BB-12. Microbiol Immunol 52, 144-155.

Molloy, M. P., Herbert, B. R., Slade, M. B., Rabilloud, T., Nouwens, A. S., Williams, K. L. \& Gooley, A. A. (2000). Proteomic analysis of the Escherichia coli outer membrane. Eur J Biochem 267, 2871-2881.

Mukai, T., Kaneko, S., Matsumoto, M. \& Ohori, H. (2004). Binding of Bifidobacterium bifidum and Lactobacillus reuteri to the carbohydrate moieties of intestinal glycolipids recognized by peanut agglutinin. Int J Food Microbiol 90, 357-362.

Nandakumar, R., Nandakumar, M. P., Marten, M. R. \& Ross, J. M. (2005). Proteome analysis of membrane and cell wall associated proteins from Staphylococcus aureus. J Proteome Res 4, 250-257.

Ong, S. E., Blagoev, B., Kratchmarova, I., Kristensen, D. B., Steen, H., Pandey, A. \& Mann, M. (2002). Stable isotope labeling by amino acids in cell culture, SILAC, as a simple and accurate approach to expression proteomics. Mol Cell Proteomics 1, 376-386.

O'Riordan, K. \& Fitzgerald, G. F. (1998). Evaluation of bifidobacteria for the production of antimicrobial compounds and assessment of performance in cottage cheese at refrigeration temperature. J Appl Microbiol 85, 103-114.

Rivera-Amill, V., Kim, B. J., Seshu, J. \& Konkel, M. E. (2001). Secretion of the virulence-associated Campylobacter invasion antigens from Campylobacter jejuni requires a stimulatory signal. J Infect Dis 183, 1607-1616.

Rodríguez-Ortega, M. J., Norais, N., Bensi, G., Liberatori, S., Capo, S., Mora, M., Scarselli, M., Doro, F., Ferrari, G. \& other authors (2006). Characterization and identification of vaccine candidate proteins through analysis of the group A Streptococcus surface proteome. Nat Biotechnol 24, 191-197.

Ruiz, L., Sánchez, B., Ruas-Madiedo, P., de los Reyes-Gavilán, C. G. \& Margolles, A. (2007). Cell envelope changes in Bifidobacterium animalis ssp. lactis as a response to bile. FEMS Microbiol Lett 274, 316-322.

Salminen, S. J., Gueimonde, M. \& Isolauri, E. (2005). Probiotics that modify disease risk. J Nutr 135, 1294-1298.
Sánchez, B., Noriega, L., Ruas-Madiedo, P., de los Reyes-Gavilán, C. G. \& Margolles, A. (2004). Acquired resistance to bile increases fructose-6-phosphate phosphoketolase activity in Bifidobacterium. FEMS Microbiol Lett 235, 35-41.

Sánchez, B., Champomier-Vergès, M. C., Anglade, P., Baraige, F., de los Reyes-Gavilán, C. G., Margolles, A. \& Zagorec, M. (2005). Proteomic analysis of global changes in protein expression during bile salt exposure of Bifidobacterium longum NCIMB 8809. J Bacteriol 187, 5799-5808.

Sánchez, B., de los Reyes-Gavilán, C. G. \& Margolles, A. (2006). The $\mathrm{F}_{1} \mathrm{~F}_{0}$-ATPase of Bifidobacterium animalis is involved in bile tolerance. Environ Microbiol 8, 1825-1833.

Sánchez, B., Champomier-Vergès, M. C., Collado, M. C., Anglade, P., Baraige, F., Sanz, Y., de los Reyes-Gavilán, C. G., Margolles, A. \& Zagorec, M. (2007). Low-pH adaptation and the acid tolerance response of Bifidobacterium longum biotype longum. Appl Environ Microbiol 73, 6450-6459.

Sánchez, B., Champomier-Vergès, M. C., Anglade, P., Baraige, F., de los Reyes-Gavilán, C. G., Margolles, A. \& Zagorec, M. (2008). A preliminary analysis of Bifidobacterium longum exported proteins by two-dimensional electrophoresis. J Mol Microbiol Biotechnol 14, 7479.

Schaumburg, J., Diekmann, O., Hagendorff, P., Bergmann, S., Rohde, M., Hammerschmidt, S., Jänsch, L., Wehland, J. \& Kärst, U. (2004). The cell wall subproteome of Listeria monocytogenes. Proteomics 4, 2991-3006.

Schell, M. A., Karmirantzou, M., Snel, B., Vilanova, D., Berger, B., Pessi, G., Zwahlen, M. C., Desiere, F., Bork, P. \& other authors (2002). The genome sequence of Bifidobacterium longum reflects its adaptation to the human gastrointestinal tract. Proc Natl Acad Sci U S A 99, 14422-14427.

Severin, A., Nickbarg, E., Wooters, J., Quazi, S. A., Matsuka, Y. V., Murphy, E., Moutsatsos, I. K., Zagursky, R. J. \& Olmsted, S. B. (2007). Proteomic analysis and identification of Streptococcus pyogenes surface-associated proteins. J Bacteriol 189, 1514-1522.

Silveira, M. G., Baumgärtner, M., Rombouts, F. M. \& Abee, T. (2004). Effect of adaptation to ethanol on cytoplasmic and membrane protein profiles of Oenococcus oeni. Appl Environ Microbiol 70, 27482755.

Speers, A. E. \& Wu, C. C. (2007). Proteomics of integral membrane proteins - theory and application. Chem Rev 107, 3687-3714.

Spence, J. M. \& Clark, V. L. (2000). Role of ribosomal protein L12 in gonococcal invasion of Hec1B cells. Infect Immun 68, 5002-5010.

Sutcliffe, I. C. \& Harrington, D. J. (2002). Pattern searches for the identification of putative lipoprotein genes in Gram-positive bacterial genomes. Microbiology 148, 2065-2077.

Tjalsma, H., Lambooy, L., Hermans, P. W. \& Swinkels, D. W. (2008). Shedding \& shaving: disclosure of proteomic expressions on a bacterial face. Proteomics 8, 1415-1428.

VanBogelen, R. A. \& Neidhardt, F. C. (1990). Ribosomes as sensors of heat and cold shock in Escherichia coli. Proc Natl Acad Sci U S A 87, 5589-5593.

Wilson, D. N. \& Nierhaus, K. H. (2005). Ribosomal proteins in the spotlight. Crit Rev Biochem Mol Biol 40, 243-267.

Wolff, S., Antelmann, H., Albrecht, D., Becher, D., Bernhardt, J., Bron, S., Büttner, K., van Dijl, J. M., Eymann, C. \& other authors (2007). Towards the entire proteome of the model bacterium Bacillus subtilis by gel-based and gel-free approaches. J Chromatogr B Analyt Technol Biomed Life Sci 849, 129-140.

Wouters, J. A., Hain, T., Darji, A., Hüfner, E., Wemekamp-Kamphuis, H., Chakraborty, T. \& Abee, T. (2005). Identification and characterization 
of di- and tripeptide transporter DtpT of Listeria monocytogenes EGD-e. Appl Environ Microbiol 71, 5771-5778.

Yuan, J., Wang, B., Sun, Z., Bo, X., Yuan, X., He, X., Zhao, H., Du, X.,

Wang, F. \& other authors (2008). Analysis of host-inducing proteome changes in Bifidobacterium longum NCC2705 grown in vivo. $J$ Proteome Res 7, 3753-3785.

Edited by: H. J. Flint 